\title{
The Practices of Student Development Education in Chinese Higher Education
}

\author{
Dan Lu \\ School of Public Manage ment \\ Yunnan University of Finance and Economics \\ Kunming, Yunnan, China \\ E-mail: yufejennyludan@126.com
}

\author{
Yadi Wang \\ Graduate and Professional Programs \\ Viterbi School of Engineering, U. of Southern California \\ Los Angeles, CA, USA \\ e-mail: yadiwang@usc.edu
}

\author{
Lijuan Yang \\ School of Public Manage ment \\ Yunnan University of Finance and Economics \\ Kunming, Yunnan, China \\ e-mail: 1752117147@qq.com
}

\begin{abstract}
Together with the fast development of higher education in China, the innovation of talents education models has become a key and challenge to modern higher education innovation in China. The lack of modern student development education recognitions from educators and college students is calling for institutions seeking for efficient methods in assisting students' developments. Thus, the research on systematic, comprehensive, purposeful and targeted student development education would benefit college students as well as other practices and researches progress on student development education.
\end{abstract}

Keywords-student development education; higher education; talents education; pratical research

\section{INTRODUCTION}

Student development Education is not a strange topic in the field of education. Since 1970s, professionals and researchers have conducted various researches from different angles. Student development education is a kind of education model or theory, which is aiming to assisting students finding career goals, life roles, developmental pathways and ultimately educating students on comprehensive and longterm develop ments.

In the 21st century, as the fast progress of global economics and technology, knowledge economy has domain the market development. There is no doubt on the significance of talented human resources to the society. Traditional education cannot fulfill the market demands any more. The reformation of talents education models has become the key and challenge of modern higher education innovation in China. The researches on improving student development education and helping college students plan their life pathways have become an important mission and urgent inquiry to higher education.

\section{PRACTiCAl MEaning Ofthe StUdent DEVELOPMENT EDUCATION}

Human development education is one of the prior missions of higher education institutions, which includes student development education that is mainly for students' future planning, personality development, living ability, interpersonal relationships, Citizen Consciousness and value system development. Students should be trained to seek for life motivations and opportunities through student development education.

\section{A. A Method in Enhancing General Education}

College students are precious resources to the country's human resources power. After graduation, students' skills of study, work and adjusting to new environments are not only their own ability for living but also in regards to the country's development. Student development education can guide students in recognizing their own personality and abilities help students defining their goals and future plans in reasonable ways. Students in colleges or universities can only make the best of their efforts of study and life planning if they set proper goals during each phase of the life.

\section{B. A Method Aiming to Help Students Life Planning}

Student development education is necessary in securing students general developments in college years as well as in improving students' capabilities in other aspects. As guided by China's educational policies, institutions are educating qualified human resources to build the socialist society in a better way, which requires not only necessary knowledge from students but also cognition ability, work ability, good characteristics and healthy psychological conditions. It is trying to train students on self-evaluation in order to discover advantages and disadvantages, from which students are encouraged to discover potentials and plan out study and 
work. Meantime, as students know better of themselves, they are also getting to know the society's trend and needs on human labors. Thus students are able to define themselves correctly, develop proper value systems going along with social needs in regards to career development.

\section{A Practical Tool for Students' Needs}

Student development education is part of life education. The care to life takes serious accounts on the existence and quality of life. Based on the concept of life education, initiating student development education is not only concerning student personal career plan but also their life development in a whole. Each life has its value of existence. Through student development education, students can make decisions of future plans depending on self-recognition so that they will be satisfied with achievements on study and the whole life. Higher education institutions have been facing problems on managing student services. Students sometimes find difficulties in study. If institutions can let students know who they are and what they would like from the first day on campus, students would have a correct self-recognition and a potential plan for the future, from which they can gain a positive attitude on life afterwards.

These years in China, as the increasing number of higher education admissions, sufficient employment has become a big is sue for college graduates. Chinese higher education has put serious attention on professional knowledge education, however emp loyers are looking for employees' judgmental, decision-making, communication and analytic abilities. Therefore, educating students to better adjusting to the society and changing life has become one of the goals for higher education development. Students have different goals in different phase in college years. Only through scientific guidance that students can know better about themselves and assess current and future situations. Student development education can inspire students' self-motivated learning, guide through a better direction and depth of knowledge intake and help students on self-management.

\section{PRACTICES OF STUDENT DEVELOPMENT EDUCATION}

The contents and methods of student development education are critical to the general education of human resources. Currently, progress of higher education in China is not on the same pace together with social requests on labors. Taking class lectures as an opening point, and integrating multiple disciplines with various methods will enhance efficiency and practical values of student development education.

\section{A. Making Use of Class Lectures}

In classes, teachers explain research theories, models and idea systems about student development with the goal to inspire students' self-discovery and motivations to plan future life.

During the four years in college or universities, teachers should offer different lectures of developments in answering different demands at different phases. One way to practice student development education is to gather a professional team of advisors. Advisors can introduce student development theories together with student cases or examples to help students understand social trends. Other methods such as class group discussions, role-play, case studies and so forth are welcome.

\section{B. Integrating Multi-disciplines Education}

Student development education can be practiced via class lectures and professional trainings. Professors of student development should take other subjects into account when designing the curriculum to improve student living skills, interpersonal abilities as well as guide students in knowing required skills for each profession. For e xample in the course of "Ethical Development and Legal Foundations", the class designers incorporate moral education into employment legal is sues education, which help students to put personal developments into social context. As in the class of "Marxism Philosophy", the class helps students analyze problems, solve problems and logical thoughts. Taught by different professors and advisors in various ways, students have opportunities to think and practice their own plans, and gather knowledge as needed.

\section{Utilizing Multiple Resources and Teaching Methods}

Higher Education Institutions should build up cooperating network including government, universities, employers and other postsecondary institutions for the purpose of empowering resources sharing and learning from each other:

1) Cooperating with Human Resources Agencies: With a general knowledge about the needs from the market, universities would advocate for beneficial policies and information support and therefore help student to increase their own competitiveness.

2) Investigating on Faculty Resources: Student development education does not only contains career planning education, but also life, survival and social skills education, which goes further into mutilple deciplines. This is also why univeristies should gather a team of professional and experienced development educators across all areas.

3) Organizing Development Planning Competetions: This can do a great favor to college students better knowing furure goals, prepareing themselves for work pressure, developing proper work values and inspiring comprehensive developments.

4) Strengthening Communications with Parents: If parents have a better idea on student performances at school and knowing provided resources to their students, they can be a great support for college students self development education.

\section{FOUNDATIONS OF STUDENT DEVELOPMENT EDUCATION}

Students have different goals in different phase in college years. And the goals vary even more among different students. Thus, student development education should take students' overall developments as the final goal and educate 
students based on their own characteristics with personalized plans at different phases. Choosing the proper education methods and making it go through all four-year experience would eventually become a relatively comprehensive student development education system. In order to build up the system professionally and efficiently, institutions are recommended to have a central distribution bureau, from which invitations and campaigns are conducted for collecting faculty and other impacting resources to broadcast the movements on student development education.

\section{A. Common Recognitions as the Ideological Guarantee}

Speaking from the student's standpoint, the student development education should get started from the first enrolling days. And the key point is to remind students of self-recognition, which means to have students reflect on themselves on interests, advantages, disadvantages, personalities, capabilities, mindset, values and ethical standards. This is considered as the psychological preparation for students self-plan as well as the foundation of student development education.

Viewing from the school's standpoint, colleges and universities know the importance of student development education to students and they would incorporate scientific assessing methods, professional advisors to assist students in defining themselves and interpret assessment results. Meanwhile, it is suggested to have senior professors or advisors to introduce the current and future trends of each major and organize fieldtrip observations at real work environments. Schools can also host panel discussions between current students and alumni about career experiences. Students are encouraged to get involved into campus activities and student organizations, which will help students adjust into the college life and develop values of life and the world. Student services in colleges, such as career centers, campus activities and program services should be working on advertising and educating students of events and information in order to generate students self-motivation and passions into the their own development education. Conferences or meetings can be hosted among institutions for best practices learning and experience sharing in order to improve student development education in a sustainable way. Educational professional are the critical components in deciding whether the goals of student development education can be achieved. So it is always worthwhile to train teachers on the importance of student developments, theories of developments and further increase faculty and staff's willing to participate in student development education.

\section{B. Effective Management as the Structural Guarantee}

Student development education is a relatively new concept to the administrations and faculty. Thus, universities should organize a leading committee, which consists of presidents, deans and chairmen, to engage innovations and trainings of student development education.

To make the taskforce targeted and effective, institutions should collect updated research theories on student development education and also share significant findings through the advanced internet technology. Regular meetings and discussion among teachers should be scheduled for the committee to review actions and work out suggestions for future goals and taskforces.

\section{Solid Actions as the Work Guarantee}

On the basis of shared recognition of the significance of student development education, institutions should pay serious attention on the actual actions. The progress of higher education student development education is expected to go further to professional and systematic directions. Outstanding and experienced faculty and staff should be selected to lead the taskforce with the strong support from senior administrations. In regards to the less experiences members, they should get the opportunities to be trained regularly to become qualified educators of student development.

To sum up, in the face of the challenge from the fast growing global economy, higher education institutions should transit concepts and models into the directions that emphasize on student development education. When refining the curriculums, administrations should think comprehensively to integrate student development education into cross-discipline education models. On the way of educating competitive human resources in the market, universities would blaze new and broad employ ment markets for students. Effective practices of student development education would benefit students in discovering themselves, defying goals, planning life pathways. Meanwhile institutions is enhancing employment rates in general and refining the brand along with the growth of the social economy.

\section{REFERENCES}

[1] Q. Li, J. Xu. Models and Practices of Student Development Education in Japanese Higher Education [J] Ideological and Theoretical Education. 2006, 11.

[2] D. Lu, P. He, Student Development Education in Enhancing Employment Competitiveness. Education for Chinese Afterschool(Theory). 2012. 12.

[3] D. Lu, P. He, C. Duan. The Experimental Management of College Students Development Education. China MachinePress, 2013 